\title{
Erratum to: The use of growth standards and corrective formulae to calculate the height loss caused by idiopathic scoliosis
}

\author{
Adrian Gardner ${ }^{1 *}$, Anna Price ${ }^{1}$, Fiona Berryman ${ }^{1}$ and Paul Pynsent ${ }^{2}$
}

\section{Erratum}

After publication of this article [1] the author brought to our attention that the formula of Stokes in Table 1 is incorrect. The correct formula is $y=\left(1+0.066 x+0.0084 x^{2}\right) /$ 10 where $x$ represents the mean Cobb angle of the largest two curves in the scoliosis and $y$ the height loss in centimetres.

\section{Author details}

${ }^{1}$ The Royal Orthopaedic Hospital NHS Foundation Trust, Bristol Road South, Northfield, Birmingham B31 2AP, UK. ${ }^{2}$ School of Clinical and Experimental Medicine, University of Birmingham, Edgbaston, Birmingham B15 2TT, UK.

Received: 12 July 2016 Accepted: 12 July 2016

Published online: 20 July 2016

\section{Reference}

1. Gardner A, Price A, Berryman F, Pynsent P. The use of growth standards and corrective formulae to calculate the height loss caused by idiopathic scoliosis. Scoliosis and Spinal Disorders. 2016;11:6.

\footnotetext{
* Correspondence: adriangardnerd@gmail.com

${ }^{1}$ The Royal Orthopaedic Hospital NHS Foundation Trust, Bristol Road South, Northfield, Birmingham B31 2AP, UK

Full list of author information is available at the end of the article
}

Submit your next manuscript to BioMed Central and we will help you at every step:

- We accept pre-submission inquiries

- Our selector tool helps you to find the most relevant journal

- We provide round the clock customer support

- Convenient online submission

- Thorough peer review

- Inclusion in PubMed and all major indexing services

- Maximum visibility for your research

Submit your manuscript at www.biomedcentral.com/submit 